\title{
ANTIBODIES TO ARBOVIRUSES IN HOUSE SPARROWS (PASSER DOMESTICUS) IN THE CZECH REPUBLIC
}

\author{
Z. JUŘICOVÁ ${ }^{1}$, I. LITERÁK ${ }^{2}$, J. PINOWSKI $^{3}$ \\ ${ }^{1}$ Institute of Vertebrate Biology, Academy of Sciences of the Czech Republic, \\ Valtice, Czech Republic \\ ${ }^{2}$ Faculty of Veterinary Medicine, University of Veterinary and Pharmaceutical Sciences, \\ Brno, Czech Republic; \\ ${ }^{3}$ Department of Vertebrate Ecology, Institute of Ecology, Polish Academy of Sciences, Dziekanów Leśny, \\ Łomianki, Poland \\ Received April 19, 2000 \\ Accepted July 27, 2000

\section{Abstract} \\ Juřicová Z., I. Literák, J. Pinowski: Antibodies to Arboviruses in House Sparrows (Passer \\ domesticus) in the Czech Republic. Acta Vet. Brno 2000, 69: 213-215. \\ From 1995 to 1997, house sparrows (Passer domesticus) $(\mathrm{n}=273)$ from suburban area close \\ to Kunín in the northeastern part of the Czech Republic were examined by using a \\ haemagglutination-inhibition test (positive titre $\geq 20$ ) for the presence of antibodies to \\ arboviruses. Antibodies to Sindbis alphavirus, West Nile flavivirus, tick-borne encephalitis \\ flavivirus, Ťahyňa bunyavirus, and Čalovo bunyavirus were detected at seroprevalences of $2.2 \%$, \\ $5.5 \%, 1.8 \%, 14.7 \%$, and $2.2 \%$, respectively. The study area seems to be an endemic focus of \\ the Ťahyňa bunyavirus occurrence. \\ Alphavirus, Flavivirus, Bunyavirus, seroprevalence, wild birds
}

Wild birds may serve as a reservoir of arboviruses in central Europe (Aspöck et al.1973; Hubálek et al. 1989). From this point of view, abundant synanthropic house sparrows were tested only few times (Ernek and Lichard 1964; Ernek et al. 1968; Sixl et al. 1973; Juřicová et al. 1998). However, in our opinion, house sparrow is the most suitable species of wild birds for studying occurrence of various arboviruses in urban and suburban areas. The reasons are its high fidelity to a locality, continuous exposition to arbovirus vectors, and easy catchability of representative numbers of sparrows for testing. For three years, we tested house sparrows from one Czech locality for the presence of antibodies to five arboviruses in order to verify the idea to use such testing for the monitoring of the arbovirus occurrences in the environment. The results of our investigation are presented in this study.

\section{Materials and Methods}

House sparrows were captured with mist-nets in a suburban agricultural area in a small village Kunín near Nový Jičín in the northeastern part of the Czech Republic. Birds were captured, killed and bled every November from 1995 to 1997.

Blood sera of sparrows were examined for antibodies to Sindbis alphavirus (SIN), West Nile flavivirus (WN), tick-borne encephalitis flavivirus (Central European encephalitis serogroup) (TBE), Ťahyňa bunyavirus (California serogroup) (TAH) and Čalovo bunyavirus (CVO). Sera were examined by using the haemagglutination-inhibition test in accordance with the method described elsewhere (Juřicová et al. 1998). For the preparation of antigens, SIN EgAr 339 SM 16, WN EgAr 101 SM 12, TAH 92 SM 12 and CVO 184 SM7 strains were used (Hubálek et al. 1989). The TBE antigen was a commercially available "HA TBE Antigen" (IMUNA, Slovak Republic). Titres of 20 and higher were considered significantly positive. Four haemagglutination units were used in the test. All the antigens used were tested prior to the haemagglutinationinhibition test with homologous and heterologous positive sera to eliminate nonspecific haemagglutination. No cross-reactions between antigens were observed.

Address for correspondence:

Doc. MVDr. Ivan Literák, CSc.
Department of Infectious Diseases and Epizootiology, Faculty of Veterinary Medicine

University of Veterinary and Pharmaceuticol Sciences,

Phone ++420-5-41 562307

Palackého 1-3, 61242 Brno, Czech Republic

E-mail: literaki@

http://www.fvu.cz/acta-vet/actavet.htm 


\section{Results and Discussion}

A total of 273 house sparrows were examined. Antibodies to SIN, WN, TBE, TAH and CVO were detected at prevalences of $2.2 \%, 5.5 \%, 1.8 \%, 14.7 \%$ and $2.2 \%$, respectively (Table 1). Titres ranged from 20 to 160 . Titres of antibodies to flaviviruses are shown in Table 2. All the examined arboviruses occurred in the studied area.

Table 1

Prevalences of antibodies to arboviruses in house sparrows (Passer domesticus) in the Czech Republic

\begin{tabular}{|l|c|c|c|c|c|}
\hline Year & $\begin{array}{c}\text { Sindbis } \\
\text { alphavirus }\end{array}$ & $\begin{array}{c}\text { West } \\
\text { Nile } \\
\text { flavivirus }\end{array}$ & $\begin{array}{c}\text { Tick-borne } \\
\text { encephalitis } \\
\text { flavivirus }\end{array}$ & $\begin{array}{c}\text { Tahyňa } \\
\text { bunyavirus }\end{array}$ & $\begin{array}{c}\text { Calovo } \\
\text { bunyavirus }\end{array}$ \\
\hline 1995 & $2 / 74 \mathrm{a}$ & $2 / 74$ & $2 / 74$ & $11 / 74$ & $1 / 74$ \\
1996 & $1 / 54$ & $3 / 54$ & $1 / 54$ & $8 / 54$ & $1 / 54$ \\
1997 & $3 / 145$ & $10 / 145$ & $2 / 145$ & $21 / 145$ & $4 / 145$ \\
Total & $6 / 273$ & $15 / 273$ & $5 / 237$ & $40 / 273$ & $6 / 273$ \\
$\%$ & 2.2 & 5.5 & 1.8 & 14.7 & 2.2 \\
Significance of differences ${ }^{b}$ & NS & NS & NS & NS & NS \\
\hline
\end{tabular}

a - Positive/tested

b - Differences between seroprevalences in individual years were tested using $\chi^{2}$ test

NS - Not significant

Table 2

Titres of antibodies to flaviviruses (WN $=$ West Nile flavivirus, $\mathrm{TBE}=$ tick-borne encephalitis flavivirus) in seropositive house sparrows (Passer domesticus)

\begin{tabular}{|lrrrrrrrrrrrrrrrrrrrr|r|}
\hline Sparrow No. & 1 & 2 & 3 & 4 & 5 & 6 & 7 & 8 & 9 & 10 & 11 & 12 & 13 & 14 & 15 & 16 & 17 & 18 & 19 & 20 \\
\hline WN & 40 & 20 & - & - & 40 & 40 & 20 & - & 20 & 20 & 80 & 40 & 20 & 40 & 40 & 80 & 20 & 20 & - & - \\
TBE & - & - & 20 & 20 & - & - & - & 20 & - & - & - & - & - & - & - & - & - & - & 40 & 20 \\
\hline
\end{tabular}

Results of our serological survey in house sparrows mostly correspond to a similar study in Poland where antibodies to SIN, WN, TBE, TAH and CVO were detected in house sparrows at seroprevalences of $1.1 \%, 2.8 \%, 1.1 \%, 2.8 \%$ and $1.1 \%$, respectively (Juřicová et al. 1998). The only striking difference is between prevalences to TAH. In the Czech study area in Kunín, the prevalence to TAH was $14.7 \%$. Near Warsaw, it was only $2.8 \%$. We learned that not only sparrows but also humans from Kunín area and close surroundings are often exposed to TAH. The prevalence of virus neutralization antibodies to TAH of $20.6 \%$ were found in the human inhabitans of that area and in summer 1970, six cases of the syndrome of human aseptic meningitis with a four-fold increase of antibodies to TAH were observed (Heinz et al. 1972). However, whether TAH or other studied viruses have an impact on the health status of sparrows remains unanswered. High prevalences of antibodies to Ťahyňa bunyavirus in both men and house sparrows suggests that the suburban area close to Kunín is an endemic focus of the Trahyňa bunyavirus occurrence.

The prevalences of arboviruses in birds are linked to the presence of specific vectors: various mosquitoes for SIN, WN, TAH, CVO and ticks Ixodes ricinus for TBE (Hubálek et al. 1989; Danielová 1990). These vectors had to attack the sparrows. Since the prevalences to studied arboviruses were not significantly different in various years, we suppose the similar amount of the attacks in the suburban environment in these years. 


\section{Protilátky proti arbovirům u vrabců domácích (Passer domesticus) v České republice}

Vrabci domácí (Passer domesticus) pocházející z vesnického, zemědělského prostředí Kunína (okr. Nový Jičín) byli v letech 1995 až 1997 vyšetřováni na přítomnost protilátek proti arbovirům. Hemaglutinačně-inhibičním testem byla vyšetřena séra 273 vrabců. Za pozitivní byl považován titr $\geq 20$. Protilátky proti alphaviru Sindbis byly detekovány v 2,2 $\%$ prevalenci, proti flaviviru West Nile v 5,5\% prevalenci, proti viru klíštové encefalitidy v 1,8 \% prevalenci, proti bunyaviru Ťahyňa v 14,7 \% prevalenci a proti bunyaviru Čalovo v 2,2\% prevalenci. Kunínsko se zdá být endemickým ohniskem výskytu bunyaviru Ťahyňa.

\section{Acknowledgements}

This study was funded by Grant No. 524/96/1059 from the Grant Agency of the Czech Republic.

\section{References}

ASPÖCK, H., KUNZ, C., PISCHER, O., BOCK, F. 1973 : Virologische und serologische Untersuchungen über die Rolle von Vögeln als Wirte von Arboviren in Ost-Österreich. Zbl. Bakteriol., I. Orig. A 244: 156-167

DANIELOVÁ, V. 1990: Circulation of arboviruses transmitted by mosquitoes in Czechoslovakia and some epidemiological sequelae (in Czech, English abstract). Českoslov. Epidemiol. Mikrobiol. Imunol. 39: 353-358

ERNEK, E., LICHARD, M. 1964: Role of the English sparrow (Passer domesticus) in the circulation of tick-borne encephalitis virus. J. Hyg. Epidemiol. Microbiol. Immunol. 8: 375-379

ERNEK, E., KOŽUCH, O., LICHARD, M., NOSEK, J. 1968: The role of birds in the circulation of tick-borne encephalitis virus in the Tribeč region. Acta Virol. 12: 468-470

HEINZ, F., HERZIG, P., AŠMERA, J., GAWLAS, W., ŠEDĚNKA B. 1972: A contribution to the problem of the Ťahyňa virus importance in the North Moravia Region. (in Czech, English sum.). Českoslov. Epidemiol. Mikrobiol. Imunol. 21: 149-158

HUBÁLEK, Z., JUŘICOVÁ, Z., HALOUZKA, J., PELLANTOVÁ, J., HUDEC, K. 1989: Arboviruses associated with birds in southern Moravia, Czechoslovakia. Acta Sc. Nat. Brno 23(7): 1-50

JUŘICOVÁ, Z., PINOWSKI, J., LITERÁK, I., HAHM, K.-H, ROMANOWSKI, J. 1998: Antibodies to Alphavirus, Flavivirus, and Bunyavirus Arboviruses in House sparrows (Passer domesticus) and Tree sparrows (P. montanus) in Poland. Avian Diseases 42: 182-185

SIXL, W., BATIKOVÁ, M., STÜNZNER, D., GREŠÍKOVÁ, M., SEKEYOVÁ, M. 1973: Serologische Untersuchung auf Antikörper gegen Arboviren bei Vögeln. Wisseschaftliche Arbeiten Burgenland, Sonderheft 1: 64-68 